\title{
COMPARATIVE OF VOTING BEHAVIOUR IN ELITE AND SLUM AREA AT LOCAL ELECTION OF JAKARTA 2017: CASE STUDY POLLING STATION (PS) 06 PEGANGSAAN MENTENG AND POLLING STATION (PS) 52 BUKIT DURI
}

\author{
Susi Dian Rahayu \\ S.IP, Universitas Indonesia, Bekasi, West Java, Indonesia, susidianrahayu@gmail.com
}

\begin{abstract}
This paper aims to analyse of comparative of voting behaviour between elite and slum areas at Local Election of Jakarta 2017. How the comparative of voting behaviour in elite and slum areas are the question of this research. The results of this research are: The first, in elite areas polling station (PS) 6 Pegangsaan, the winner of the local election first round are Ahok-Djarot. They are an incumbent who have some issues like blasphemy, relocation inhumane, and any others. But, in other hand many people argue that Ahok-Djarot is best choice for governor and vice governor for Jakarta because of their achievement in last period, like the cleaning of Ciliwung river, public transportation, and relocation slums areas. But, at second round of local election, Ahok - Djarot are loss in there because most of voters AHY (candidate who loss at first round) voted Anies-Sandi. The most of Ahok-Djarot voters in polling station (PS) 6 said that they are not influenced by a variety of negative issues of the candidate. Second, in slum areas Polling station (PS) 52 Bukit Duri, the winner of the local election are Anies-Sandi. Anies- Sandi are Muslim candidate who have many achievement and their character are friendly, polite and have a good manner. Most of Anies-Sandi voters sure that if Anies-Sandi being governor and vice governor of Jakarta, policy of relocation will be held humanity with emphasis on dialogue. By the result of research, the conclusion is most of voters in Jakarta used rational and sociology factor for their reason to choose governor and vice governor.
\end{abstract}

Keywords: Local election, voting behaviour, elite, slum,

\section{INTRODUCTION}

The year of 2017, is a year of local elections simultaneously for the second wave, followed by 101 regions throughout Indonesia, one of which is the Election of the Governor of DKI Jakarta Province. In the implementation, a local election has a high enough prestige among local people, let alone the implementation of elections held in the capital city, namely DKI Jakarta. Prestigious can be seen from the 
high public interest to keep up with the information of Jakarta Governor Election, even though they are not the people of DKI Jakarta.

The local election of DKI Jakarta in 2017, followed by three pairs of candidates, namely Agus Harimurti Yudhoyono-Sylviana Murni promoted by Democrat Party, the United Development Party (PPP), the National Awakening Party (PKB) and the National Mandate Party (PAN). The second pair, Basuki Tjahaja PurnamaDjarot Saiful Hidayat or popular with name Ahok-Djarot, was promoted by the Indonesian Democratic Party of Struggle (PDI P), Golkar Party, Hanura Party and Nasdem Party and an incumbent candidate. The next candidate pair number three namely Anies Rasyid Baswedan-Sandiaga Salahuddin Uno who is a candidate of the Gerindra Party and Prosperous Justice Party (PKS).

The chaotic about the polemic of Jakarta elections in 2017 has long been a trending topic in various media, even long before the determination of candidate pairs. For example, one year before the elections, the public has been disrupted by the movement of a million ID cards for Ahok initiated by "Friends Ahok". The movement seemed to disqualify political parties as if the terms of interest and expensive tariffs for candidacy, so that Ahok better forward through the independent path. The frenzied upheaval continues to the process of elections, including cases of religious blasphemy involving one of a candidate, the circulation of false E-IDs allegedly for the benefit of one of a candidate, eviction case, criminalization of clerics, and others.

Therefore, in the political system in Indonesia that is still influenced by the traditionalism of power, the process of change of power and the determination of policies is not necessarily based on rational choices, primordialism in determining the choice still colouring the process of democratization in Indonesia especially at the time of the implementation of elections DKI Jakarta in 2017. Primordialism referred to primordialism based on ethnicity, religion, community groups until the belief is adopted. One of the dominant social factors in politics in Indonesia to date is the religious factor, even Riswanda Imawan states that the political position in Indonesia can be synchronized with religion.( Riswanda, 1999)

Local election of DKI Jakarta 2017 was held in two rounds, the first round on February 15, 2017, and resulted in two candidate pairs to advance to the second round on April 19, 2017, namely Basuki Tjahaja Purnama- Djarot Saiful Hidayat and Anies Rashid Baswedan - Sandaiga Salahuddin Uno. In the second round, the pair Anies Baswedan - Sandiaga Uno won the contestation of Pilkada. This research is about to analyze the comparison of voting behavior in Jakarta from two different aspects, namely elite and slum area. The focus of this research is Polling Station 6 in Pegangsaan sub-district of Menteng, Central Jakarta, and Polling Station 52 Bukit Duri. Polling Station 6 Pegangsaan is one of the unique polling stations because it is located between headquarters of two candidates namely, Agus Harimurti Yudhoyono-Sylviana Murni and Basuki Tjahaja Purnama-Djarot Saiful Hidayat. In addition, most voters at the polling station are also from among the elite, such as artists, businessmen, academics, state officials and others. Whereas Polling station 52 Bukit Duri one of slum area which is relocated in flats of Rawa Bebek but most of evictees still vote in Bukit Duri.

For knowing of voting behaviour in both of polling station, this paper use theory of voting behaviour. Voting Behaviour is an activity that is so complicated by involving various aspects of sociological, psychological, and rational. One of them is what Durkheim meant about social facts that exist outside the human individual but (unconsciously) has forced and controlled people to do or not to do an act (Upe, 2008) Or is it from of rational action performed human being as an active and creative subject. As the social action theory believes. However, generally in field experience, both are often difficult to be separated expressly from each other.

Focussing of voting behaviour, voting has a very big role. The definition of the voting behaviour may be interpreted as a person's preference or preference in electing to exercise their right to vote or not to exercise the right to vote. Self-chosen behaviour is defined in many understandings, as Surbakti puts it, "the act of voting by individuals closely related to the decision-making to vote or not to vote in an election". When voters decide to vote then voters will elect or support certain candidates. (Fera, 2009)

While Brennan and Lomasky (1977) and Fiorina (1976) tend to consider voting in elections an "expressive" behavior. This can be said as well as supporters of soccer teams who provide support to the team. (Firmansah, 2009, p.105) In understanding the behaviour of choosing, many approaches can be used. At least, in this research will use three approaches, namely:

\section{a. Sociological Approach}

The sociological approach states that sociological factors are believed to be the guidance for voters in determining their choice. These sociological factors including social class background, social stratification, social group, religion, occupation, educational level and social conditions. In this approach, the strength of 
the group is highly visible. The grouping can be based on age, work, culture, and religion. The sociological approach explaining the characteristics and social grouping is a factor affecting voter behavior and voting is essentially a group experience. (Nursal, 2004)

\section{b. Psychological Approach}

The psychological approach explains that voters are tied to a particular candidate party or candidate due to partisan or symbolic ties. This partisan and symbolic bond is usually deeply rooted, thus making political preference stable. This approach emphasizes the importance of party identification in influencing voting decisions. (Cambell, 1966)

According to Adman Nursal, psychology approach is based on attitude and socialization. A person's attitude greatly influences his political behaviour. The attitude is formed through long-lasting socialization; even it could be since a prospective voter is still aged. This association is called party identification. (Cambell, p 59) Some voter behaviour indicators that use psychological approaches include the relatively political "political" electorate, the openness of information (the open press), have an identity politics from birth, favourable.

\section{c. Rational Choice Approach}

This approach refers to two main orientations, namely the issue orientation and candidate orientation. The candidate's orientation refers to a person's attitude towards a candidate regardless of the background of the party, while the orientation of the issue relates to strategic issues, vision-mission of the candidate. In this case, voters will continue to follow the progress of the candidates to be elected. They will try to calculate as precisely as possible about what they will choose. They tend to be smart and will not be quick to make choices. They may still be volatile in assessing candidates by looking at the candidate's programs.

So the research question of this paper is how the comparative of Voting Behaviour between Voters in Elite and Slum Areas at Local Election of Jakarta 2017: Case Study Polling Station (PS) 06 Pegangsaan Menteng and Polling Station (PS) 52 Bukit Duri?

\section{METHODOLOGY}

This research adopted qualitative research. The main method uses in this research are observation and literature study to obtain the objective results. Researcher observated in polling station (PS) 06 Pegangsaan at first and second round which is one of elite area in Jakarta, and polling station (PS) 52 Bukit Duri, one of slum area which is relocated in flats of Rawa Bebek but most of evictees still vote in Bukit Duri. Researchers do in depth interview with some of voters in booth of polling station. The data were collected with legal procedure which is helped by the committee of election. Literature study towards some journals, scientific papers, newspapers and other sources which are further analysed by the researcher. This research use theory of voting behaviour consisting of rational choice, psychology and sociology factor to analyse of voting behaviour in elite and slum areas.

\section{RESULT}

\subsection{Voting Behaviour at Elite Area}

Polling station 6 Pegangsaan is located at Borobudur Street, Pegangsaan sub district which is not far from the headquarter of Agus Harimurti Yudhoyono-Sylviana Murni in Wisma Proklamasi, Pegangsaan headquarter of Basuki Tjahaja Purnama-Djarot Saiful Hidayat or Ahok-Djarot at the homestead of Borobudur. But the most surprising in the first round electoral process is related to the acquisition of AgusSylvi vote's, which should win because it is near with their headquarter but got the least votes.

Table 1:Voter turnout at Polling Station 6 Pegangsaan (first round)

\begin{tabular}{|l|l|l|}
\hline No & Candidate & Voter \\
\hline 1. & Agus Harimurti Yudhoyono- Sylviana Murni & 93 \\
\hline 2. & Basuki Tjahaja Purnama-Djarot Saiful Hidayat & 248 \\
\hline 3. & Anies Rasyid Baswedan-Sandiaga Salahuddin Uno & 180 \\
\hline
\end{tabular}

The victories of Ahok-Djarot and Anies -Sandi, and Agus-Sylvi's defeat in the first round can be analysed using several voting behaviour approaches such as rational choice factors, psychological factors, and 
sociological factors. Voting Behaviour approach with shortlisting analysis of rational choice is usually oriented to candidates referring to a person's attitude towards a candidate regardless of the background of the party, while the orientation of the issue relates to strategic issues, vision, and mission of the candidate. Similarly, the reason for choosing by some voters in Polling station 6 Pegangsaan which said that one of the considerations in determining the choice is to see the vision and mission of candidate, and the result of candidate debate broadcast by several national television stations. According to one of voter Ahok-Djarot, the reason for choosing the candidate is because of evidence of the performance the pair has achieved, which is an incumbent couple. According to him, mission vision is all good, but it is difficult to convince him as a voter whether the mission vision will be realized. Related to emerging issues, such as ethnic issues, religious blasphemy, and some hoax issues raised before the election, voters with rational choice approach tend not to be affected by it. If looking at the majority of voters in PS 6 coming from the elite middle class, voter tendencies with the "profit-loss" consideration by analysing the work program offer offered by each candidate are considered reasonable, that is categorized in the rational choice approach.

Furthermore, the sociological approach emphasizes sociological factors as the basis for choosing a person, including social class background, social stratification, social group, religion, occupation, educational level and certain social conditions. In addition to the rational choice approach factor, the victory of Basuki Tjahaja Purnama - Djarot Saiful Hidayat pair, the third number of Anies Rasyid Baswedan Sandiaga Salahuddin Uno and the defeat of Agus Harimurti Yudhoyono - Sylviana Murni were also influenced by sociological factors. Among them, religious factors, ethnicity and news coverage in the media that occurred at that time. This is the same as the Anies-Sandi supporters, who always shout with the call "Allahu Akbar!" Whenever the committee calls the "three" number when the vote count is followed by applause. However, when the committee called "two", the supporters cheered "huuuuuu", and when the committee called "one", the supporters were silent without any comment. This went on until the committee finished the vote counting.

Some voters of Anies-Sandi admitted that the reason of they vote Anies-Sandi because of politeness factor and social piety of candidate. One of the voters confessed that he was very impressed with Anies's polite and calm manner, Anies's intelligence and experience while pioneering the activities of "Indonesia Mengajar", is a testament to the sincerity of Anies to build the country. Related to Anies Baswedan's dismissal from the post of Minister of Education and Culture, they call this a political factor, and assume that is unfair for Anies. The background is also an indication of a sociological approach.

Some voters also use religious factors to determine their political choices. This is not just happening to Muslim voters who are called to elect Muslim leaders. Non-Muslim voters do so; they choose leaders based on their religion and beliefs. Issues in various media, The 'Ahok-Djarot' couple are not only supported by Christian and Muslim voters, but also other people as fellow minority solidarity.

At second round of local election DKI Jakarta, in Polling station 6, candidate of Anies-Sandi is the winner in this polling station. Based on data about local election of DKI Jakarta in polling station 6 Pegangsaan, AhokDjarot get the stagnant vote, but Anies-Sandi have risen up for their vote. The vote of Anis-Sandi came from voters of Agus Harimurti Yudhoyono-Sylvi at first round local election.

Table 2: Voter turnout at Polling Station 6 Pegangsaan (second round)

\begin{tabular}{|l|l|l|}
\hline No & Candidate & Voter \\
\hline 2. & Basuki Tjahaja Purnama- Djarot Saiful Hidayat & 259 \\
\hline 3. & Anies Rasyid Baswedan-Sandiaga Salahuddin Uno & 291 \\
\hline
\end{tabular}

Most of voters Agus-Sylvi at first round said that in second round they choose Anies-Sandi. Although they didn't like with Anies-Sandi, but most of them think that Anies-Sandi is better than Ahok-Djarot. In other hand, most of them said that the Governor of DKI Jakarta must come from Moslem candidate, and they afraid if Ahok-Djarot wins at the local election, Jakarta will dominate with Chinese.

By the result of first and second round of local election DKI Jakarta in Polling Station 6 Pegangsaan which is representative of voters in elite areas, it can be conclude that the dominant factor which influence of voting behaviour of voters in Polling station 6 Pegangsaan are rational choice and sociology factor. Although lose in second round, Ahok-Djarot prove that they have millitant voters. Most of millitant voters of Ahok Djarot in Polling Station 6 Pegangsaan said that they choose Ahok-Djarot because they have proved that they can be a good governor and vice governor. Ahok-Djarot's policy is good for Jakarta. In other hand, most of voters in 
Polling station 6 Pegangsaan are high class community, like actor, actrees, bussinessman, public figure, profesor which come from any ethnicity. Religiously, voters in polling station 6 Pegangsaan come from various religions like Moslem, Protestant, Catholic, Budhis and Hindu.

Although lose at first round, Anies-Sandi win at second round of local election DKI Jakarta. By the data of local election, the opposite of Anies-Sandi, Ahok-Djarot have a stagnant vote, while vote of Anies-Sandi have increased. Increasing of votes for Anies-Sandi come from Agus-Sylvi voters.

\subsection{Voting Behaviour at Slum Area}

Polling station 52 Bukit Duri is one of a slum area in Jakarta which is relacoted by Jakarta government when Ahok-Djarot were governor and vice governor. DKI Jakarta Province is one of the provinces that implement relocation policy, with the aim of one of them to normalize Ciliwung River. As is known, Jakarta is a flood subscription area. The flood that always inundated Jakarta caused by several factors, including the lack of green open space and water absorption, as well as the silting of the river caused by the proliferation of illegal settlements. The growing growth of illegal settlements in Jakarta is considered a separate problem for the government of DKI Jakarta Province. Therefore, the Provincial Government of DKI Jakarta keeps trying to arrange the city and slum area by displacing the people who live in river banks or illegal areas like in Bukit Duri.

Most of voters in Polling station have been relocated in flat which is provided by DKI Jakarta Government. But, they aren't registered in Polling Station where they are relocated. So, they come to Bukit Duri again for voting of local election DKI Jakarta 2017. Most of voters in Polling station 52 Bukit Duri are very exited to give their vote for candidate Governor and vice governor DKI Jakarta. At first and second round of local election DKI Jakarta, Anies-Sandi wins absolutely.

Table 3: Voter turnout at Polling Station 52 Bukit Duri (first and second round)

\begin{tabular}{|l|l|l|l|}
\hline No & Candidate & $\begin{array}{l}\text { Voter } \\
\text { 1st Round }\end{array}$ & $\begin{array}{l}\text { Voter } \\
\text { 2nd Round }\end{array}$ \\
\hline 1. & Agus Harimurti Yudhoyono- Sylviana Murni & 59 & - \\
\hline 2. & Basuki Tjahaja Purnama- Djarot Saiful Hidayat & 29 & 19 \\
\hline 3. & Anies Rasyid Baswedan-Sandiaga Salahuddin Uno & 350 & 340 \\
\hline
\end{tabular}

Based on voting behaviour theory which explaine that there are three parts of voting behaviour, include rational choice, sociology factor and psycology factor most of voter in Polling Station 52 using their vote with approach of sociology factors, psycology factors and rational choice factors. The sociological approach which sees social, religious, and place factors is influential on voter behavior in polling station 52 Bukit Duri. The condition of the majority Muslim community and is a sympathizer of PKS is one of the factors of AniesSandi's advancement. This is one of the reasons behind the voting community in Polling Station 52 to choose the candidate pair number 3 compared to pair number 1 , although both have a religious social background as a Muslim.

Basically, most of voters in Polling station 52 Bukit Duri are lower middle class. They aren't affiliate with any political parties, but there is political parties which intensive empowering them with its programs, the parties is PKS (in English: Prosperous justice parties). In other hand, the dominant factor why Anies-Sandi win absolutely in Polling Station 52 Bukit Duri are most of voter disappointed with Ahok-Djarot policy which have relocated them without any communication. They hope if Anies-Sandi being a governor and vice governor, Anies-Sandi will be more humanity than Ahok-Djarot.

In a rational approach that saw voters perform the calculations of the gains obtained in determining their choice, the researcher sees this as the main reason that the majority of voters in TPS 52 Bukit Duri did not choose the candidate pair of number 2 . This is indicated by the policy previously taken on the candidate pair number 2 when served as the Governor of DKI Jakarta, the relocation of housing residents. The implication of the policy is that people object to policies that are deemed not to take sides with the interests of the citizens. Communities who reject the policy on the basis of grounds such as no compensation to citation dues on new dwellings. This is the basis for the calculation of the voting community in PS 52 who feel disadvantaged over the policy and considers not to choose the incumbent partner as a way of evaluating leadership democratically. 


\section{CONCLUSION}

Implementation of Jakarta Election invites various public enthusiasms to follow its development, not only domestic public but also foreign public. Polling Station 6 Pegangsaan and Polling station 52 Bukit Duri have own uniqueness compared to other Polling station in Jakarta. Polling station 6 Pegangsaan Besides its location in the middle of the elite area, Polling station is also located between two headquarter candidates are Agus Harimurti Yudhoyono-Sylviana Murni and Basuki Tjahaja Purnama- Djarot Saiful Hidayat. While Polling station 52 Bukit Duri is a polling station in the area of slum area, the average voter in this polling station is eviction.

There are several factors that influence the voting of behaviour in Polling station 6 Pegangsaan and Polling station 52 Bukit Duri including a rational choice factor, psychological approach and sociologist approach. The three approaches have an influence over each other on the victory and defeat of the candidate's vote in the contestation of the election. The reason for choosing based on the rational choice factor in the first and second local election of DKI in Polling station 6 is the consideration of the performance and vision of the mission offered by the candidate in the candidate debate some time ago. While sociological factors, influenced by social, religious, and ethnic issues that developed in the community, as well as influential in Polling station 6 Pegangsaan. While on Psychological approaches, factors that influence the behavior of voting people in the elections in DKI Jakarta Poling station 6 is the similarity of party affiliation, participants or successful teams of one of the candidates in the poll station.

While the factors that influence the voting behaviour in polling station 52 Bukit Duri is a factor of sociology, rational choice and psychological. Sociologically, voters in polling station 52 Bukit Duri are mostly Muslim. The existence of religious blasphemy issue by Ahok also influenced the behavior of their choosing. While the rational choice factor, the majority of voters are victims of evictions during the reign of Ahok-Djarot, so they feel aggrieved by the policy and choose Anies-Sandi which is considered more humanist and vision-mission and pro poor.

\section{ACKNOWLEDGMENT}

The author would like to express thanks and appreciate for LPDP (Lembaga Pengelola Dana Pendidikan) for providing financial support both for study in magister Political science at Universitas Indonesia and also support for attending this conference and publication. The author also gratitude and apreciate to all respondent in Polling station 6 Pegangsaan and Polling station 52 as their contribution in this research.

\section{REFERENCE LIST}

\section{Books:}

Cambell, August et.al, The American Voter (USA: John Willey and Sons, Inc, 1966)

Firmansyah.Marketing Politik "Antara Realitas dan Pemahaman". Jakarta:Yayasan Obor Indonesia, 2007.

Jocelyn A.J.,Evans, Voting and Voters: An Introduction, London: SAGE Publication,2004

Schumpeter dalam Georg Sorensen. Demokrasi dan Demokratisasi,Proses dan Prospek dalam Sebuah Dunia yang sedang Berkembang, Yogyakarta: Pustaka Pelajar, 2003.

Nasution, Hariani Fera, .Perilaku Pemilih Pada Pemilihan Gubernur Sumatera Utara Secara Langsung di Kabupaten Labuhan Batu ).2009.USU Repository 2009

Nursal, Adman, Political Marketing,Strategi Memenangkan Pemilu. Jakarta. Gramedia Pustaka Utama, 2004.

Upe, Ambo, Sosiologi Politik Kontemporer: Kajian Tentang Rasionalitas Perilaku Politik Pemilih di Era Pemilihan Kepala Daerah Secara Langsung, Jakarta : Prestasi Pustaka, 2008.

Varma,SP.Teori Politik Modern, Jakarta: PT Raja Grafindo Persada,2007.

\section{Journals:}

Riswanda Imawan, "Kampanye Tanpa Huru Hara”, dalam Jurnal Ikatan Sarjana Komunikasi (Vol. IV, 1999) 